\title{
RELATIONSHIP BETWEEN HEART RATE AND OXYGEN CONSUMPTION DURING STEADY-STATE SWIMMING IN CALIFORNIA SEA LIONS
}

\author{
BY P. J. BUTLER ${ }^{1}$, A. J. WOAKES ${ }^{1}$, I. L. BOYD ${ }^{2}$ AND S. KANATOUS 3 \\ ${ }^{1}$ School of Biological Sciences, The University of Birmingham, Birmingham \\ B15 2TT, UK, ${ }^{2}$ British Antarctic Survey, High Cross, Madingley Road, \\ Cambridge, CB3 OET, UK and ${ }^{3}$ Department of Marine Biology, \\ Texas A \& M University, PO Box 1675, Galveston, TX 77553, USA
}

Accepted 27 May 1992

\begin{abstract}
Summary
Heart rate $\left(f_{\mathrm{H}}\right)$ and rate of oxygen uptake $\left(\dot{V}_{\mathrm{O}_{2}}\right)$ were measured in six subadult California sea lions Zalophus californianus while they were at rest and while they were swimming for 15 min at controlled speeds of up to $1.4 \mathrm{~m} \mathrm{~s}^{-1}$ and pulling loads of up to $3 \mathrm{~kg}$.

There was a good linear relationship between $f \mathrm{H}$ and $\dot{V}_{\mathrm{O}_{2}}$ in all six sea lions. The slopes of the individual regression lines varied between 2.66 and 4.36 beats $\mathrm{ml}^{-1} \mathrm{O}_{2} \mathrm{~kg}^{-1}$, the intercepts varied between 48.2 and 63.0 beats $\min ^{-1}$ and $r^{2}$ varied between 0.82 and 0.93 . The mean relationship for all six sea lions is $f \mathrm{H}=(57.4 \pm 2.0)+(3.58 \pm 0.23) \dot{V}_{\mathrm{O}_{2}}, r^{2}=0.89 \pm 0.01$. The mean of the lowest $\dot{V}_{\mathrm{O}_{2}}$ values was $5.1 \pm 0.4 \mathrm{ml} \mathrm{min}^{-1} \mathrm{~kg}^{-1}$ and the mean of the highest $\dot{V}_{\mathrm{O}_{2}}$ values was $26.9 \pm 1.9 \mathrm{ml} \mathrm{min}^{-1} \mathrm{~kg}^{-1}$. The means of the lowest and highest values of $f_{\mathrm{H}}$ were less extreme, being $72 \pm 3$ beats $\min ^{-1}$ and $155 \pm 5$ beats min $^{-1}$, respectively.

It is concluded that, by using data storage devices and grouped data, $f \mathrm{H}$ could be used in otariids as an indicator of aerobic metabolism under field conditions, in particular for breeding females during the period of lactation.
\end{abstract}

\section{Introduction}

A number of workers have investigated the relationship between heart rate $(\mathrm{fH})$ and rate of oxygen consumption $\left(\dot{V}_{\mathrm{O}_{2}}\right)$, with a view to using the former to estimate the latter in free-ranging animals (see Butler, 1989, for a review). Certainly, under steady-state conditions, there is a good linear relationship between the two variables in most vertebrates that have been studied. Under natural conditions, however, animals may not always be in a steady state. Perhaps an extreme example of this is seen in aquatic birds and mammals during diving, when gas exchange is intermittent and there are large excursions in $f \mathrm{H}$ associated with submergence and surfacing (Fedak et al. 1988; Butler, 1991, 1992). However, at the cellular level, these animals may be in a steady state (Butler, 1992). Despite 
the substantial variations in heart rate associated with diving activity, Fedak (1986) demonstrated that there was a linear relationship between $f \mathrm{H}$ and $\dot{V}_{\mathrm{O}_{2}}$ in a grey seal during increasing swimming activity if average $\dot{V}_{\mathrm{O}_{2}}$ and $f \mathrm{H}$ values over complete dive cycles were used. A similar situation has been described for two common seals and a sea lion (Williams et al. 1991).

The potential usefulness of $f \mathrm{H}$ as an indicator of aerobic metabolic rate in freeranging marine mammals has been discussed by Butler (1992). A problem would be obtaining the data from animals at sea, and the only really feasible way of accomplishing this is to use data storage devices that can be retrieved from the animals at some stage. For Weddell seals, this has been achieved when they return to a breathing hole in the ice (Hill et al. 1987), but for most phocid seals recapture would only be reliably possible from one breeding season to the next. For otariids, however, the energetic cost of foraging could be determined using the heart rate method for breeding females, which return to their pups at regular intervals during the period of lactation (Gentry and Kooyman, 1986).

It was decided, therefore, to determine the relationship between $f_{\mathrm{H}}$ and $\dot{V}_{\mathrm{O}_{2}}$ in the California sea lion, Zalophus californianus, at the temperature-controlled water channel facility, Scripps Institution of Oceanography, San Diego (see Feldkamp, 1987, for details).

\section{Materials and methods}

Six subadult sea lions of either sex were used in the study. They had been beached and held for 1-3 months at Sea World, San Diego, before being transferred to the Physiological Laboratory at Scripps where they were kept in a circular channel for up to 30 days before being used. They were fed twice a day on a diet of herring and mackerel supplemented with vitamins. Their masses, just before the experiments, ranged from 25.7 to $38.1 \mathrm{~kg}$ (mean $32.3 \pm 1.6 \mathrm{~kg} \mathrm{S.E.}$ ).

The sea lions were trained to swim under a respirometer hood in the flume. As they could swim faster than the maximum water speed $\left(1.4 \mathrm{~m} \mathrm{~s}^{-1}\right)$ in the flume, the work load was increased by adding weights to a line and pulley attached to the back of the animal (see Williams et al. 1991, for details). When it was clear that each sea lion would swim for at least $15 \mathrm{~min}$ at $1.4 \mathrm{~m} \mathrm{~s}^{-1}$, a data logger for capturing heart rate (Woakes, 1992) was placed within a sealed metal box attached to the back of the animal with epoxy glue. Two electrocardiogram (ECG) electrodes (self-adhesive human stress electrodes, NDM, Dayton Ohio) were placed on shaved, degreased skin in the mid line of the back at the levels of the pectoral and pelvic girdles, and attached to the data logger. These electrode positions gave clean ECG patterns, even in active animals. Plastic covers were placed over the electrodes and attached to the surrounding fur with epoxy glue. The animal was then placed into the test section of the water channel.

The animals were fasted for $18-24 \mathrm{~h}$ before an experiment and the water temperature was $22 \pm 1^{\circ} \mathrm{C}$ (range). Oxygen uptake was determined (see Davis et al. 1985; Feldkamp, 1987) while the animal rested or swam in the flume for 
$15 \mathrm{~min}$ at a controlled speed of up to $1.4 \mathrm{~m} \mathrm{~s}^{-1}$ and pulling a weight of up to $3 \mathrm{~kg}$. The combinations of water speed and load were chosen arbitrarily (see Woakes and Butler, 1983) but when resting values of the two variables were required the animals were left for more than one 15 -min period before the next period of swimming. The data logger averaged and stored $f_{\mathrm{H}}$ every $30 \mathrm{~s}$. Data were downloaded from the logger at the end of each experiment via a purpose-made interface to a lap-top computer (316LT, Dell). The mean values of $f \mathrm{H}$ and of $\dot{V}_{\mathrm{O}_{2}}$ were taken over the last 5 min of each 15 -min period, i.e. when $\dot{V}_{\mathrm{O}_{2}}$ had stabilized. Each animal was tested continuously for $24 \mathrm{~h}$. Where appropriate, mean values are given \pm s.E. and all values of $\dot{V}_{\mathrm{O}_{2}}$ are at STPD. The Tukey multicomparison test was used to determine which regression slopes and then which elevations were significantly different from which others (Zar, 1984). Two lines were deemed to be significantly different from each other when $\alpha<0.05$.

\section{Results}

The lowest mean value of $\dot{V}_{\mathrm{O}_{2}}$ recorded from the six sea lions was $5.1 \pm 0.4 \mathrm{ml} \mathrm{min}^{-1} \mathrm{~kg}^{-1}$ and the highest mean value $\left(26.9 \pm 1.9 \mathrm{ml} \mathrm{min}^{-1} \mathrm{~kg}^{-1}\right)$ was 5.3 times the resting value (Fig. 1). The lowest and highest values of $f \mathrm{H}$ were less extreme, the latter $\left(155 \pm 5\right.$ beats $\left.\min ^{-1}\right)$ being only 2.2 times greater than the former (Fig. 1), which was $72 \pm 3$ beats $\mathrm{min}^{-1}$.

An example of the individual data points for a $24 \mathrm{~h}$ experiment with one sea lion is shown in Fig. 2 and this demonstrates the clear linear relationship between the

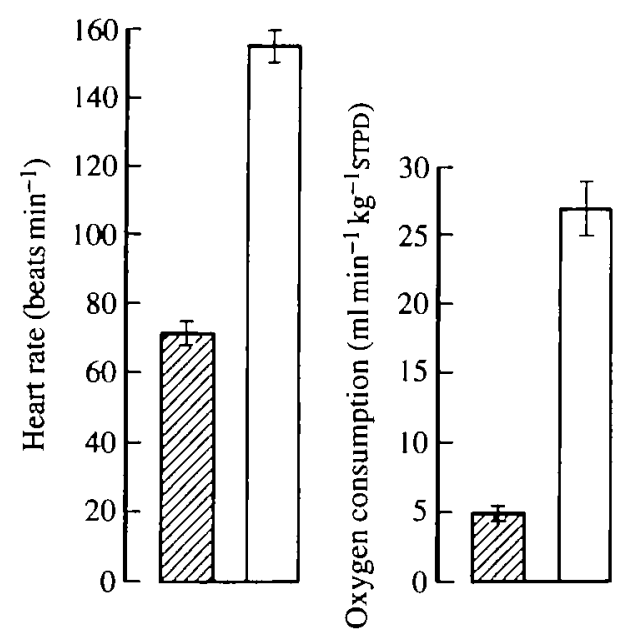

Fig. 1. Mean ( \pm s.E.) of the lowest (hatched columns) and highest (open columns) recorded values of heart rate and rate of oxygen consumption from six subadult Californian sea lions (mean mass $32.3 \pm 1.6 \mathrm{~kg}$ ) at rest and while swimming in a water channel. 


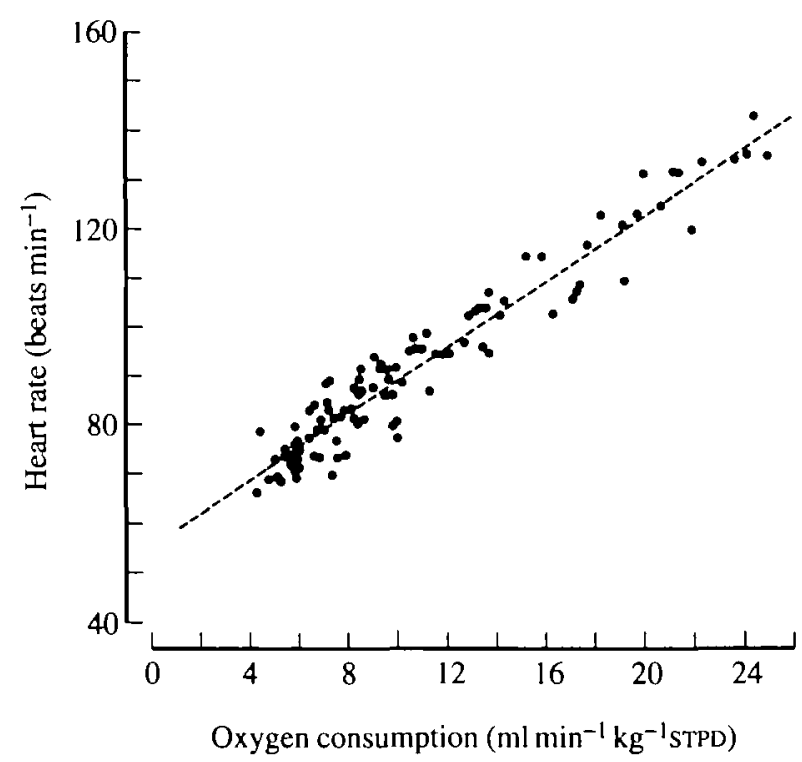

Fig. 2. Relationship between heart rate $(f \mathrm{H})$ and rate of oxygen consumption $\left(\dot{V}_{\mathrm{O}_{2}}\right)$ in a subadult, female Californian sea lion $(29.5 \mathrm{~kg})$ at rest and while swimming at different speeds (up to $1.4 \mathrm{~m} \mathrm{~s}^{-1}$ ) and carrying different loads (up to $3 \mathrm{~kg}$ ). $f \mathrm{H}=$ $(55.4 \pm 1.2)+(3.34 \pm 0.1) \dot{V}_{\mathrm{O}_{2}}, r^{2}=0.93, N=96$.

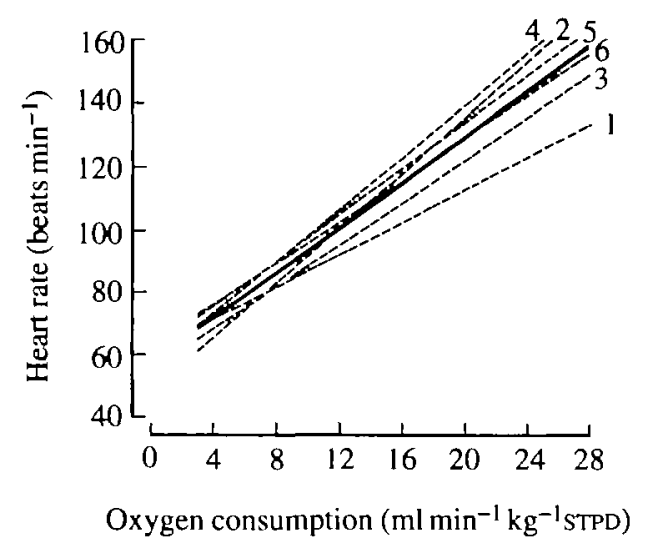

Fig. 3. Regression lines of the relationship between heart rate $(f \mathrm{H})$ and rate of oxygen consumption $\left(\dot{V}_{\mathrm{O}_{2}}\right)$ for six individual subadult Californian sea lions (---). The mean regression line for all six sea lions is also given (-). The mean relationship is $f \mathrm{H}=(57.4 \pm 2.0)+(3.58 \pm 0.23) \dot{V}_{\mathrm{O}_{2}}, r^{2}=0.89 \pm 0.01$. The number next to each regression line corresponds to that in Table 1 .

two variables. All the individual linear regression lines, plus the mean of these, are illustrated in Fig. 3. The slopes ( \pm s.E.) of the individual lines varied between $2.66 \pm 0.14$ and $4.36 \pm 0.31$ beats $\mathrm{ml}^{-1} \mathrm{~kg}^{-1}$, the intercepts varied between $48.2 \pm 3.5$ 
Table 1. Values of a (intercept), b (regression coefficient or slope) \pm s. E. and of $\mathrm{r}^{2}$ (coefficient of determination) for the linear regression equations of heart rate ( $\mathrm{f} H$ ) against oxygen uptake $\left(\dot{\mathrm{V}}_{O_{2}}\right)$ in six individual sea lions, where $\mathrm{f}_{H}=\mathrm{a}+\mathrm{b} \dot{\mathrm{V}}_{O_{2}}$

\begin{tabular}{lcccc}
\hline No. & $\begin{array}{c}\text { Body mass } \\
(\mathrm{kg})\end{array}$ & $\begin{array}{c}a \\
\left(\text { beats } \mathrm{min}^{-1}\right)\end{array}$ & $\begin{array}{c}b \\
\left(\text { beats } \mathrm{ml}^{-1} \mathrm{~kg}^{-1}\right)\end{array}$ & $r^{2}$ \\
\hline 1 & 34.9 & $60.07 \pm 2.54$ & $2.66 \pm 0.14$ & 0.91 \\
2 & 33.0 & $48.20 \pm 3.46$ & $4.36 \pm 0.31$ & 0.88 \\
3 & 29.5 & $55.35 \pm 1.16$ & $3.34 \pm 0.09$ & 0.93 \\
4 & 32.8 & $56.73 \pm 2.00$ & $4.13 \pm 0.21$ & 0.82 \\
5 & 25.7 & $60.92 \pm 1.87$ & $3.68 \pm 0.12$ & 0.92 \\
6 & 38.1 & $63.03 \pm 2.26$ & $3.32 \pm 0.16$ & 0.87 \\
Mean & $32.3 \pm 1.6$ & $57.4 \pm 2.0$ & $3.58 \pm 0.23$ & $0.89 \pm 0.01$ \\
\hline
\end{tabular}

Table 2. Details of Tukey multicomparison tests on the slopes and elevations of the linear regression lines shown in Fig. 3 (see also Table 1)

\begin{tabular}{|c|c|c|c|c|c|}
\hline \multirow{2}{*}{$\begin{array}{l}\text { Regression } \\
\text { line } \\
\text { number }\end{array}$} & \multicolumn{5}{|c|}{ Regression line number } \\
\hline & 2 & 3 & 4 & 5 & 6 \\
\hline \multicolumn{6}{|l|}{ Slopes } \\
\hline 1 & $\mathrm{~S}$ & NS & $\mathrm{S}$ & $\mathrm{S}$ & NS \\
\hline 2 & & NS & NS & NS & NS \\
\hline 3 & & & $\mathrm{~S}$ & NS & NS \\
\hline 4 & & & & NS & NS \\
\hline 5 & & & & & NS \\
\hline \multicolumn{6}{|l|}{ Elevations } \\
\hline 1 & - & $\mathrm{S}$ & - & - & $\mathrm{S}$ \\
\hline 2 & & NS & $S$ & NS & NS \\
\hline 3 & & & - & $\mathrm{S}$ & $\mathrm{S}$ \\
\hline 4 & & & & NS & NS \\
\hline 5 & & & & & NS \\
\hline
\end{tabular}

$S$ indicates a significant difference and NS a non-significant difference between two regression lines $(\alpha<0.05, q=0.05,384,6=4.05)$.

and $63.0 \pm 2.3$ beats $\min ^{-1}$ and $r^{2}$ varied between 0.82 and 0.93 (Table 1). The mean relationship for all six animals is $f_{\mathrm{H}}=(57.4 \pm 2.0)+(3.58 \pm 0.23) \dot{V}_{\mathrm{O}_{2}}$, $r^{2}=0.89 \pm 0.01$. From Table 2 it can be seen that, for four pairs of regression lines, the slopes are significantly different from one another and for another five pairs, the elevations are significantly different.

\section{Discussion}

The lowest mean value for $\dot{V}_{\mathrm{O}_{2}}$ is slightly less than the resting values reported by 
Feldkamp (1987) and Ponganis etal. (1991) $\left(6.55 \mathrm{ml} \mathrm{min}^{-1} \mathrm{~kg}^{-1}\right.$ and $6 \mathrm{ml} \mathrm{min}^{-1} \mathrm{~kg}^{-1}$, respectively) for California sea lions of a similar mass in the same swim flume. Although low water temperature is known to cause an increase in resting $\dot{V}_{\mathrm{O}_{2}}$ in this species, (T. M. Williams, R. W. Davis, S. Kanatous, A. J. Tirpak and I. L. Boyd, in preparation), water temperature cannot be the complete explanation for the difference between the present values and those values quoted above. The higher value obtained by Feldkamp (1987) was from animals in water at $27^{\circ} \mathrm{C}$, while the animals used by Ponganis et al. (1991) were in water at $17^{\circ} \mathrm{C}$. The lowest mean $\dot{V}_{\mathrm{O}_{2}}$ value obtained in the present study was only $20 \%$ greater than the standard metabolic rate for terrestrial mammals obtained from the allometric formula of Kleiber (1961), which is, $\dot{V}_{\mathrm{O}_{2}}\left(\mathrm{ml} \mathrm{min}^{-1}\right)=10.13 M^{0.75}$, where $M$ is body mass in $\mathrm{kg}$ and assuming that $11 \mathrm{O}_{2} \equiv 4.8 \mathrm{kcal}$. These data support the proposal of Lavigne et al. (1986), that pinnipeds do not have a resting metabolic rate substantially above that of terrestrial mammals of similar body mass.

The highest mean $\dot{V}_{\mathrm{O}_{2}}$ obtained in the present study is similar to the values reported by Feldkamp (1987) and Williams et al. (1991) for sea lions swimming at an equivalent speed of approximately $3 \mathrm{~m} \mathrm{~s}^{-1}$, which is similar to the maximum surface swimming velocities measured in Galapagos and Hooker's sea lions (Ponganis et al. 1990 b). Also, Northern fur seals have mean swimming velocities of less than $2 \mathrm{~m} \mathrm{~s}^{-1}$ (Ponganis et al. 1992). None of the workers claim that their highest $\dot{V}_{\mathrm{O}_{2}}$ value is the maximum oxygen uptake $\left(\dot{V}_{\mathrm{O}_{2} \max }\right)$ for their animals. However, it is of interest that three of the same sea lions were used soon after the present study, and $\dot{V}_{\mathrm{O}_{2}}$ at the highest speed/mass load combination $\left(1 \mathrm{~m} \mathrm{~s}^{-1}\right.$, $4.5 \mathrm{~kg}$ ) was approximately $30 \mathrm{ml} \mathrm{min}^{-1} \mathrm{~kg}^{-1}$ (T. M. Williams, R. W. Davis, S. Kanatous, A. J. Tirpak and I. Boyd, in preparation). In comparison, however, Ponganis et al. (1991) report a $\dot{V}_{\mathrm{O}_{2}}$ of $45 \mathrm{ml} \mathrm{min}^{-1} \mathrm{~kg}^{-1}$ in a California sea lion of $37 \mathrm{~kg}$ mass swimming at $1 \mathrm{~m} \mathrm{~s}^{-1}$ with a $4 \mathrm{~kg}$ load. There is no obvious explanation for the difference in the $\dot{V}_{\mathrm{O}_{2}}$ recorded at similar work loads in these two studies, although the latter authors do state that their animals 'only sustained this work load for short periods of time.... and obviously would not consistently work at this level'. It is not clear what Ponganis et al. (1991) meant by 'short periods of time', but wild terrestrial mammals will run for 5-15 min near or at $\dot{V}_{\mathrm{O}_{2} \max }$ (Taylor et al. 1981). We would suggest, therefore, that $\dot{V}_{\mathrm{O}_{2} \max }$ for the sea lions used in the above studies is somewhere between 30 and $40 \mathrm{ml} \mathrm{min}^{-1} \mathrm{~kg}^{-1}$, which is some $30-45 \%$ below the $\dot{V}_{\mathrm{O}_{2} \max }$ for a $32 \mathrm{~kg}$ wild terrestrial animal (Taylor et al. 1981). It is interesting to note that Costa et al. (1989), using the doubly-labelled water method, estimated the at-sea metabolic rate of foraging for $35 \mathrm{~kg}$ female Antarctic fur seals to be $29.3 \mathrm{ml} \mathrm{min}^{-1} \mathrm{~kg}^{-1}$. Also, Elsner (1986) reported a $\dot{V}_{\mathrm{O}_{2} \max }$ for $16-41 \mathrm{~kg}$ harbor (common) seals of $33 \mathrm{ml} \mathrm{min}^{-1} \mathrm{~kg}^{-1}$ and the highest $\dot{V}_{\mathrm{O}_{2}}$ measured by Ponganis et al. (1990a) for $33 \mathrm{~kg}$ harbor (common) seals was $36 \mathrm{ml} \mathrm{min}^{-1} \mathrm{~kg}^{-1}$.

The important aspect, as far as the present study is concerned, is that the $f \mathrm{H} / \dot{V}_{\mathrm{O}_{2}}$ relationship was tested from resting to levels that are probably routinely reached in the wild. This indicates that $f \mathrm{H}$, recorded using data storage devices, could be 
used with otariids as an indicator of aerobic metabolism under field conditions and over extended periods (see Butler, 1992, for further discussion). From the present set of data, the mean formula for estimating $\dot{V}_{\mathrm{O}_{2}}$ from $f \mathrm{H}$ is $\dot{V}_{\mathrm{O}_{2}}=(0.26 \pm 0.02) f \mathrm{H}-(13.47 \pm 1.44), r^{2}=0.89$, where $\dot{V}_{\mathrm{O}_{2}}$ is in $\mathrm{ml} \mathrm{min}^{-1} \mathrm{~kg}^{-1}$ and $f_{\mathrm{H}}$ is in beats $\min ^{-1}$. Clearly, it will be necessary to establish the details of the relationship between $f \mathrm{H}$ and $\dot{V}_{\mathrm{O}_{2}}$ in other species but, if linearity is assumed, this could be achieved with two sets of data points (at rest and at a relatively high level of activity).

Experiments on aquatic and semi-aquatic birds have indicated that $f_{\mathrm{H}}$ is not a good predictor of $\dot{V}_{\mathrm{O}_{2}}$ for individuals, although it is very good if grouped data from a number of individuals are used (Bevan et al. 1992; Nolet et al. 1992). As 9 out of the 15 comparisons between pairs of linear regressions were significantly different in the present study, the need to use grouped data probably also applies to marine mammals. Bevan et al. (1992) have also demonstrated that this technique is accurate when the relationship between $f \mathrm{H}$ and $\dot{V}_{\mathrm{O}_{2}}$ is derived from one group of birds and applied to another group of the same species. This is the case, even if the conditions under which the data were obtained are different e.g. at different environmental temperatures (Bevan and Butler, 1992). In this context, it appears that $\dot{V}_{\mathrm{O}_{2}}$ during swimming in California sea lions is independent of water temperature (T. M. Williams, R. W. Davis, S. Kanatous, A. J. Tirpak and I. Boyd, in preparation). Thus, it is concluded that the same constraints and advantages of the $f_{H}$ technique that have been described for aquatic birds exist for otariid seals.

This project is funded by NERC. The authors wish to thank Dr G. L. Kooyman, Dr T. M. Williams and Dr R. W. Davis and all those at the PRL, Scripps Institution of Oceanography, for their help and assistance. They also wish to thank Brad Andrews, Jim Antrim, Tom Goff and the animal care staff at Sea World for assisting in obtaining and holding the sea lions. This work was performed under permit no. 742 issued under the Marine Mammal Protection Act.

\section{References}

Bevan, R. M. AND BUtLer, P. J. (1992). The effects of temperature on the oxygen consumption, heart rate and deep body temperature during diving in the tufted duck, Aythya fuligula. J. exp. Biol. 163, 139-151.

Bevan, R. M., Keijer, E. and Butler, P. J. (1992). A method for controlling the feeding behaviour of aquatic birds: heart rate and oxygen consumption during dives of different duration. J. exp. Biol. 162, 91-106.

Butler, P. J. (1989). Telemetric recording of physiological data from free-living animals. In Toward a More Exact Ecology (ed. P. J. Grubb and J. B. Whittaker), pp. 63-84. Oxford: Blackwell Scientific Publications.

Butler, P. J. (1991). Exercise in birds. J. exp. Biol. 160, 233-262.

Butler, P. J. (1992). To what extent can heart rate be used as an indicator of metabolic rate in free-living marine mammals? In Recent Advances in Marine Mammal Science (ed. I. L. Boyd). Symp. Zool. Soc. Oxford: Oxford University Press (in press).

Costa, D. P., Croxall, J. P. ANd Duck, C. D. (1989). Foraging energetics of Antarctic fur seals in relation to changes in prey availability. Ecology 70, 596-606. 
Davis, R. W., Williams, T. M. and Kooyman, G. L. (1985). Swimming metabolism of yearling and adult harbor seals Phoca vitulina. Physiol. Zool. 58, 590-596.

Elsner, R. (1986). Limits to exercise performance: Some ideas from comparative studies. Acta physiol. scand. $128,45-51$.

FEDAK, M. A. (1986). Diving and exercise in seals: a benthic perspective. In Diving in Animals and Man (ed. A. Brubakk, J. W. Kanwisher and G. Sudnes), pp. 11-32. Trondheim: Tapir Publishers.

Fedak, M. A., Pullen, M. R. and Kanwisher, J. (1988). Circulatory responses of seals to periodic breathing: heart rate and breathing during exercise and diving in the laboratory and open sea. Can. J. Zool. 66, 53-60.

Feldkamp, S. D. (1987). Swimming in the California sea lion: morphometrics, drag and energetics. J. exp. Biol. 131, 117-135.

Gentry, R. L. And Kooyman, G. L. (eds) (1986). Fur Seals: Maternal Strategies on Land and at Sea. Princeton, NJ: Princeton University Press.

Hill, R. D., Schneider, R. C., Liggins, G. C., Schuette, A. H., Eliot, R. L., Guppy, M., HochachKa, P. W., Qvist, J., Falke, K. J. and Zapol, W. M. (1987). Heart rate and body temperature during free diving of Weddell seals. Am. J. Physiol. 253, R344-R351.

KLEIBER, M. (1961). The Fire of Life: An Introduction to Animal Energetics. New York: Wiley.

Lavigne, D. M., Innes, S., Worthy, G. A. J., Kovacs, K. M., Schmitz, O. J. and Hickie, J. P. (1986). Metabolic rates of seals and whales. Can. J. Zool. 64, 279-284.

Nolet, B. A., Butler, P. J., Masman, D. AND Woakes, A. J. (1992). Estimation of daily energy expenditure from heart rate and doubly labelled water in exercising geese. Physiol. Zool. (in press).

Ponganis, P. J., Gentry, R. L., Ponganis, E. P. and Ponganis, K. V. (1992). Analysis of swim velocities during deep and shallow dives of two northern fur seals, Callorhinus ursinus. Mar. Mamm. Sci. 8, 69-75.

Ponganis, P. J., Kooyman, G. L. and Zornow, M. H. (1991). Cardiac output in swimming California sea lions, Zalophus californianus. Physiol. Zool. 64, 1296-1306.

Ponganis, P. J., Kooyman, G. L., Zornow, M. H., Castellini, M. A. and Croll, D. A. $(1990 a)$. Cardiac output and stroke volume in swimming harbor scals. J. comp. Physiol. B 160, 473-482.

Ponganis, P. J., Ponganis, E. P., Ponganis, K. V., Kooyman, G. L., Gentry, R. L. and Trillmich, F. (1990b). Swimming velocities in otariids. Can. J. Zool. 68, 2105-2115.

Taylor, C. R., Maloiy, G. M. O., Weibel, E. R., Langman, V. A., Kamau, J. M. Z., Seeherman, H. J. And Heglund, N. C. (1981). Design of the mammalian respiratory system. III. Scaling maximum aerobic capacity to body mass: wild and domestic mammals. Respir. Physiol. 44, 25-37.

Williams, T. M., Kooyman, G. L. And Croll, D. A. (1991). The effect of submergence on heart rate and oxygen consumption of swimming seals and sea lions. J. comp. Physiol. B 160, 637-644.

Woakes, A. J. (1992). An implantable data logging systen for heart rate and body temperature. In Wildlife Telemetry (ed. I. G. Priede). Town: Horword Ltd. (in press).

Woakes, A. J. ANd ButLer, P. J. (1983). Swimming and diving in tufted ducks, Aythya fuligula, with particular reference to heart rate and gas exchange. J. exp. Biol. 107, 311-329.

ZAR, J. H. (1984). Biostatical Analysis. 2nd edition. London: Prentice-Hall International Editions. 